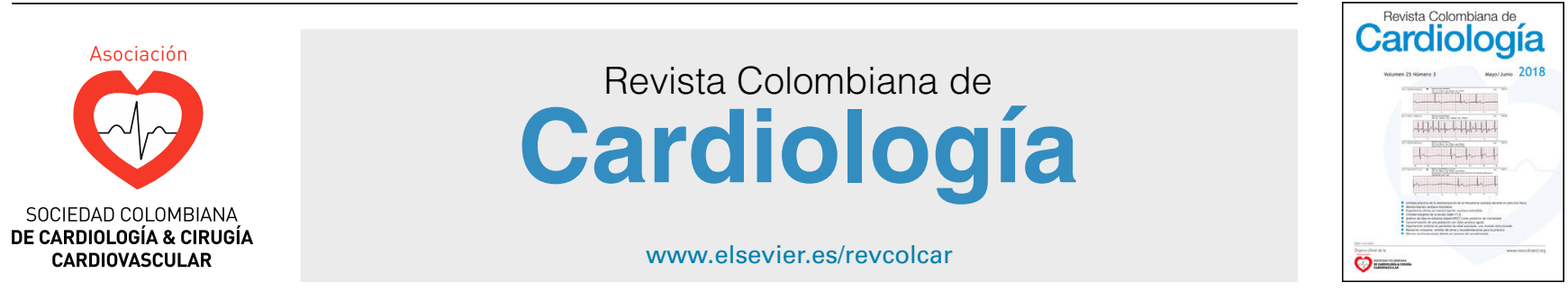

ADULT CARDIOLOGY - ORIGINAL ARTICLES

\title{
Identification of potentially inappropriate cardiovascular prescriptions in the elderly using Beers' criteria
}

\author{
Alejandro Castro-Rodríguez ${ }^{a}$, Manuel E. Machado-Duque ${ }^{a, b}$, Diego A. Medina-Morales ${ }^{a}$, \\ Jorge E. Machado-Alba ${ }^{a, *}$ \\ a Grupo de Investigación en Farmacoepidemiología y Farmacovigilancia, Universidad Tecnológica de Pereira-Audifarma S.A. \\ Pereira, Colombia \\ ${ }^{\mathrm{b}}$ Fundación Universitaria Autónoma de las Américas, Pereira, Colombia
}

Received 30 August 2018; accepted 12 February 2019

Available online 25 September 2019

\section{KEYWORDS \\ Cardiovascular \\ disease; \\ Geriatrics; \\ Pharmacology}

\begin{abstract}
Introduction: improper use of medication is becoming more frequent and can cause physical or physiological damage.

Objective: to determine the frequency of potentially inappropriate prescriptions of cardiovascular drugs according to Beers' criteria in a population of colombian patients.

Method: cross-sectional study conducted during november 2016 using a population database of 326,192 adults over 65 years of age who were eligible to receive drugs included in the cardiovascular system category according to the Beers' criteria. The frequency of potentially inappropriate prescriptions was determined and investigated in relation to sociodemographic variables.

Results: the mean subject age was $74.6 \pm 7.6$ years (range:65-100 years). It was found that $11.3 \%(n=36894)$ of the elderly presented at least one potentially inappropriate prescription for cardiovascular conditions. The most frequent finding was the use of aspirin in patients older than 80 years of age followed by the use of prazosin for hypertension in patients over 65 years of age or in patients who consulted emergency services for syncope. The other criteria were present in less than $1 \%$ of patients, and in 16 out of 33 treatment drugs, no patients exposed to potentially inappropriate prescriptions were found. Within the criteria based on drug-drug interactions, the most frequent were loop diuretics along with prazosin (6.4\%).

Conclusions: the prevalence of potentially inappropriate prescriptions in an elderly population of patients in Colombia is lower than that reported worldwide. In addition, there is a need to re-evaluate the Beers' criteria in this population and adjust the guidelines according to results of pharmacovigilance of active pharmaceutical substances available in Colombia.

(c) 2019 Sociedad Colombiana de Cardiología y Cirugía Cardiovascular. Published by Elsevier España, S.L.U. This is an open access article under the CC BY-NC-ND license (http:// creativecommons.org/licenses/by-nc-nd/4.0/).
\end{abstract}

\footnotetext{
* Corresponding author.

E-mail address: machado@utp.edu.co (J.E. Machado-Alba).
} 


\section{PALABRAS CLAVE \\ Enfermedad \\ cardiovascular; \\ Geriatría; \\ Farmacología}

\section{Criterios de Beers en la identificación de prescripciones de uso cardiovascular potencialmente inapropiadas en ancianos}

\begin{abstract}
Resumen
Introducción: el uso incorrecto de medicamentos es cada vez más frecuente y puede causar daños físicos o fisiológicos.

Objetivo: determinar la frecuencia de las prescripciones de medicamentos de uso cardiovascular potencialmente inapropiadas según criterios de Beers en una población de pacientes colombianos.

Métodos: estudio de corte transversal, a partir de una base de datos de una población de 326.192 adultos mayores de 65 años, durante el mes de noviembre de 2016, susceptibles de recibir medicamentos incluidos en los criterios de Beers en la categoría de sistema cardiovascular, determinando la frecuencia de prescripciones potencialmente inapropiadas, así como la identificación de variables sociodemográficas.

Resultados: la edad promedio fue de 74,6 \pm 7,6 años (rango 65-100 años). Se halló que el 11,3\% $(n=36894)$ de los ancianos tuvo al menos una prescripción potencialmente inapropiada para condiciones cardiovasculares. El criterio más frecuente fue el uso de aspirina en mayores de 80 años, seguido del empleo de prazosín para la hipertensión arterial en mayores de 65 años, o en pacientes que consultaron por síncope a los servicios de urgencias. Los demás criterios se presentaban en menos del $1 \%$ de pacientes y en 16 de 33 fármacos de cuidado no se halló ningún paciente expuesto. Entre los criterios basados en interacciones fármaco-fármaco, el más frecuente fue diuréticos de asa junto con prazosín $(6,4 \%)$.

Conclusiones: la prevalencia de prescripciones potencialmente inapropiadas en una población de ancianos colombianos es menor a la reportada en el mundo. Además, se plantea la necesidad de reevaluar los criterios de Beers en dicha población y ajustarlos de acuerdo con los informes de farmacovigilancia y principios activos disponibles en Colombia.

(c) 2019 Sociedad Colombiana de Cardiología y Cirugía Cardiovascular. Publicado por Elsevier España, S.L.U. Este es un artículo Open Access bajo la licencia CC BY-NC-ND (http:// creativecommons.org/licenses/by-nc-nd/4.0/).
\end{abstract}

\section{Introduction}

Higher life expectancy has translated into greater demand for medical services, more comorbidities and increasing consumption of prescription medicine. ${ }^{1}$ Improper use of medication is becoming more frequent and can cause physical or physiological damage, which results in high health system costs. 2,3

On the other hand, the correct use of a drug is one that is supported by clear evidence where clinical benefit outweighs the risk of potential undesirable consequences and there are no safer alternatives. ${ }^{3}$ Different studies have found that more than $20 \%$ of the drugs prescribed for elderly patients are potentially inappropriate prescriptions. $^{4-7}$

Potentially inappropriate prescriptions are frequent in the United States and Europe and are estimated to be close to $12 \%$ in outpatients and up to $40 \%$ in institutionalized patients. ${ }^{8}$ In addition, there is a clear association between the number of drugs prescribed and inadequate prescription. ${ }^{8}$ Identification of this problem in Colombia showed that in 423 patients older than 65 years of age, $21.5 \%$ received some type of potentially inappropriate prescription. $^{9}$

These medications are often prescribed as a first line of care or with limited effectiveness in the elderly, who, due to age-related physiological changes, coupled with changes in pharmacokinetics and pharmacodynamics, multiple comorbidities and use of several drugs, express a greater vulnerability to adverse reactions, which can even trigger serious problems such as delirium, gastrointestinal bleeding, falls and fractures. , $^{3,8-11}$

Drugs used at a higher frequency or duration than indicated, those with a high risk of drug-drug or drug-disease interactions, and duplications or use of drugs of the same class, ${ }^{11}$ are all considered to be potentially inappropriate prescriptions. Potentially inappropriate prescriptions also include the failure to use beneficial drugs that are clinically indicated but, for various reasons, are often not prescribed. ${ }^{11}$

The Beers' criteria represent a widely used tool in North America that includes a listing of at least 53 drugs that may be potentially inappropriate in older adults. ${ }^{2}$ The Beers' criteria are very broad and cover many systems, which is why we decided to work only with those of the cardiovascular group given the importance of these pathologies on the mortality of the country. Many of the drugs involved are commonly used, and because this information is not known in Colombia, the objective was to determine the frequency of potentially inappropriate prescriptions for cardiovascular drugs according to the Beers' criteria updated in 2015 in a population of patients treated at an outpatient clinic in 2016. 


\section{Methods}

This cross-sectional study was based on a database of approximately 4.5 million people affiliated with Colombia's Health System (SGSSS) in six Health Promoting Entities (EPS) representing approximately $20.3 \%$ of the actively affiliated population in the country and $8.2 \%$ of the whole colombian population, in 116 cities in all regions of the country. A total of 326,192 adults over 65 years of age who were eligible for medications were identified, which corresponded to $5.8 \%$ of the affiliated subjects.

From the database of Audifarma SA, the largest dispenser of drugs to patients affiliated with the country's SGSSS, all patients over 65 years of age who had received any of the drugs included in the Beers' criteria in the cardiovascular system category during November 2016 were selected. ${ }^{2}$ The information was reviewed and validated before its analysis by the researchers. The database of Audifarma S.A has been used successfully in multiple investigations on the use of medicines in the country. Age, sex, city of residence were identified. From the identified older adults, a search was made according to the International Classification of Diseases (ICD-10) and Anatomical Therapeutic Chemical (ATC) codes of the drugs that were included in the recipe to evaluate the following criteria:

- Congestive heart failure: avoid non-steroidal antiinflammatory drugs (NSAIDs), calcium channel blockers, thiazolidinediones, cilostazol, and dronedarone.

- Hypertension: avoid the use of peripheral alpha 1 blockers, central-acting alpha blockers and short-acting nifedipine.

- Syncope: avoid anticholinergics, peripheral alpha1 blockers, tricyclic antidepressants, chlorpromazine and olanzapine.

- Chronic kidney disease (CKD) (decreased glomerular filtration rate [GFR] $<30 \mathrm{~mL} / \mathrm{min}$ ): avoid use of amiloride, apixaban, dabigatran, edoxaban, enoxaparin, fondaparinux, rivaroxaban, spironolactone, and triamterene.

- Acetyl salicylic acid in primary prevention: avoid in persons over 80 years of age.

- Dabigatran: use with caution in patients over 75 years of age and with GFR $<30 \mathrm{ml} / \mathrm{min}$.

- Prasugrel: use with caution in persons over 75 years of age.

- Vasodilators: use with caution due to syncope risk.

- Interactions: avoid angiotensin-converting-enzyme inhibitors (ACEs) + amiloride; ACEs + lithium carbonate; loop diuretics + lithium carbonate; loop diuretics + peripheral alpha 1 blockers; warfarin + amiodarone; and warfarin + NSAIDs.

- Avoid the use of amiodarone, digoxin, and dronedarone in heart failure and atrial fibrillation.

- The following variables were collected: age, gender and cardiovascular drugs included in one of the three lists of updated Beers' criteria (includes only those drugs for cardiovascular use or the criteria relevant to patients with cardiovascular disease).

This study was endorsed by the Bioethics Committee of the Universidad Tecnológica de Pereira in the category of "research without risk". This study complied with the bioethical principles established by the Declaration of Helsinki. The data were anonymous and an informed consent was not required.

\section{Plan of analysis}

The statistical package IBM SPSS Statistics, version 24 (IBM, USA) for Windows was used to analyze the data. Frequencies and proportions were obtained for at-risk patients and those with appearance of the criteria and for the continuous variables, central tendency measures were used as mean and standard deviation.

\section{Results}

Out of a total of 326,192 older adults identified in the database, the mean age was $74.6 \pm 7.6$ years (range 65 100 years), 158,219 (48.5\%) were older than 75 years and $99,027(30.3 \%)$ older than 80 years.

Of the elderly subjects studied, 36894 (11.3\%) presented with at least one potentially inappropriate prescriptions according to the Beers' criteria for cardiovascular conditions.

The majority of criteria were present in less than $1 \%$ of patients, and in 16 out of 33 treatment drugs, no patients exposed to potentially inappropriate prescriptions were identified. We identified 86,162 hypertensive patients, 2055 with atrial fibrilation, 522 with congestive heart failure and 82 with syncope.

In patients older than 65 years with arterial hypertension, the most common criteria found was the use of prazosin and other alpha 1 blockers, followed by central-acting alpha blockers. The most frequent criteria was the use of low doses of acetylsalicylic acid in patients older than 80 years of age (Table 1). There were very few patients who met the criteria of receiving NSAIDs, cardio-depressant calcium channel blockers and dronedarone having congestive heart failure, as well as patients with syncope who received prazosin or rivastigmine (Table 2 ).

The criteria based on drug-drug interactions are presented in Table 3. The most frequent interaction was loop diuretics along with prazosin (6.4\%), and the other interactions were present at very low frequencies. But there were also criteria that did not meet any case such as ACEs plus triamterene, or ACEs plus lithium, or warfarin with amiodarone (Table 4).

For many criteria of the disease-drug category no patients were at risk, as occurred with congestive heart failure with thiazolidinediones, or with cilostazol, and cases of syncope with antipsychotics.

\section{Discussion}

This study identified a low frequency of potentially inappropriate prescriptions according to the Beers' criteria for cardiovascular conditions. These criteria are used as a tool to identify and prevent the use of potentially inappropriate drugs in the elderly. Considering the introduction of new drugs in the market and the discontinuation of others, 
Table 1 Potentially inappropriate drugs to avoid or use with caution in a database of 326,192 elderly people. Colombia 2016.

\begin{tabular}{|c|c|c|c|c|}
\hline Drug & $\begin{array}{l}\text { Hypertensive } \\
\text { population at risk } \\
\text { (n) }\end{array}$ & $\begin{array}{l}\text { n (Population } \\
\text { with the Beers' } \\
\text { criterion) }\end{array}$ & Proportion (\%) & Criterion \\
\hline $\begin{array}{l}\text { Peripheral alpha } 1 \\
\text { blockers }\end{array}$ & 86,162 & & & $\begin{array}{l}\text { Risk of orthostatic } \\
\text { hypotension. Do }\end{array}$ \\
\hline Prazosine & & 2479 & 2.90 & not use as a first \\
\hline Terazosin & & 9 & 0.01 & line in \\
\hline Doxazosin & & 144 & 0.16 & hypertension \\
\hline Clonidine & & 1438 & 1.66 & \\
\hline Methyildopa & & 40 & 0.04 & \\
\hline Dronedarone & $\begin{array}{l}\text { Population with } \\
\mathrm{AF}^{1} \text { or } \mathrm{CHF}^{2} \text { at risk } \\
\text { (n) }\end{array}$ & $\begin{array}{l}\text { n (Population with } \\
\text { the } \\
\text { Beers'criterion) }\end{array}$ & Proportion (\%) & Criterion \\
\hline Dronedarone in $\mathrm{AF}$ & 2,055 & 3 & 0.14 & $\begin{array}{l}\text { The outcomes are } \\
\text { worse. }\end{array}$ \\
\hline $\begin{array}{l}\text { Dronedarone in } \\
\mathrm{CHF}\end{array}$ & 522 & 1 & 0.10 & \\
\hline Digoxin & $\begin{array}{l}\text { Population with } \mathrm{AF} \\
\text { or CHF or CKD } \\
\text { at risk (n) }\end{array}$ & $\begin{array}{l}\text { n (Population with } \\
\text { the Beers' } \\
\text { criterion) }\end{array}$ & $\begin{array}{l}\text { Proportion } \\
(\%)\end{array}$ & Criterion \\
\hline Digoxin in AF & 2,055 & 31 & 1.50 & $\begin{array}{l}\text { Do not use as a } \\
\text { first line of } \\
\text { management. } \\
\text { there are other } \\
\text { better } \\
\text { alternatives. }\end{array}$ \\
\hline Digoxin in CHF & 522 & 32 & 6.10 & $\begin{array}{l}\text { Uncertain effects } \\
\text { versus benefit }\end{array}$ \\
\hline
\end{tabular}

AF: atrial fibrilation. CHF: congestive heart failure. CKD: chronic kidney disease.

Table 2 Potentially inappropriate drugs, by drug-disease interaction to avoid or use with caution in a database of 326,192 elderly people. Colombia 2016.

\begin{tabular}{|c|c|c|c|c|c|}
\hline Risk situation & $\begin{array}{l}\text { Population at risk } \\
\text { (n) }\end{array}$ & $\begin{array}{l}\text { Potentially } \\
\text { Inappropriate Drug }\end{array}$ & $\begin{array}{l}\text { n (Population } \\
\text { with the Beers' } \\
\text { criterion) }\end{array}$ & Proportion (\%) & Criterion \\
\hline \multirow{3}{*}{$\begin{array}{l}\text { Congestive heart } \\
\text { failure }\end{array}$} & 522 & All NSAIDs & 1 & 0.10 & Exacerbates \\
\hline & & $\begin{array}{l}\text { Cardio-depressant } \\
\text { Calcium channel } \\
\text { blockers }\end{array}$ & 3 & 0.50 & $\begin{array}{l}\text { congestive heart } \\
\text { failure }\end{array}$ \\
\hline & & Dronaderone & 1 & 0.10 & \\
\hline \multirow[t]{2}{*}{ Syncope } & 82 & Prazosine & 2 & 2.40 & $\begin{array}{l}\text { Risk of } \\
\text { hypotension or } \\
\text { bradycardia }\end{array}$ \\
\hline & & Rivastigmine & 1 & 1.21 & \\
\hline
\end{tabular}

NSAIDs: nonsteroidal anti-inflammatory drugs.

it is important for Colombia to have updated information on the change of prevalence of drug prescriptions that may be associated with risks, adverse events or worse outcomes according to the Beers' criteria. ${ }^{2}$

When comparing demographic data among the included patients, the mean age was slightly less than that reported by Martinez-Arroyo et al. in Mexico in a similar study during 2014 (74.6 \pm 7.6 vs. $76.6 \pm 5.9$ years, respectively) because that research only included patients older than 70 years of age. $^{12}$

In their review of the Beers' criteria, Aparasu et al. reported that the prevalence of potentially inappropriate prescriptions was $14.0 \%$ in the elderly in $2000,{ }^{13}$ which is similar to what was found in this study. However, the prevalence of potentially inappropriate prescriptions in this study was higher than that reported by Willcox et al., who 
Table 3 Potentially inappropriate drugs, which should be used with caution in a database of 326,192 elderly people. Colombia 2016.

\begin{tabular}{|c|c|c|c|c|}
\hline Drug & $\begin{array}{l}\text { Population at risk } \\
\text { (n) }\end{array}$ & $\begin{array}{l}\text { n (Population } \\
\text { with the Beers' } \\
\text { criterion) }\end{array}$ & Proportion (\%) & Criterion \\
\hline $\begin{array}{l}\text { ASA }^{1} \text { in patients } \\
>80 \text { years old }\end{array}$ & 99,027 & 29,753 & 29.90 & $\begin{array}{l}\text { Little benefit } \\
\text { in decreasing } \\
\text { cardiovascular } \\
\text { risk. }\end{array}$ \\
\hline $\begin{array}{l}\text { Dabigatran in } \\
\text { Patients }>75 \text { years } \\
\text { old }\end{array}$ & 158,219 & 704 & 0.44 & $\begin{array}{l}\text { In patients older } \\
\text { than } 75 \text { years, } \\
\text { increases risk of } \\
\text { GIB vs warfarin }\end{array}$ \\
\hline $\begin{array}{l}\text { Prasugrel in } \\
\text { patients }>75 \text { years } \\
\text { old }\end{array}$ & 158,219 & 3 & 0.001 & $\begin{array}{l}\text { In patients older } \\
\text { than } 75 \text { years, } \\
\text { increases risk of } \\
\text { GIB vs warfarin }\end{array}$ \\
\hline
\end{tabular}

ASA: acetylsalicylic acid. GIB: gastrointestinal bleeding.

Table 4 Pharmacological interactions to be avoided in older adults from a database of 326,192 elderly people. Colombia 2016.

\begin{tabular}{|c|c|c|c|c|}
\hline Risk situation & $\begin{array}{l}\text { Population at risk } \\
\text { (n) }\end{array}$ & $\begin{array}{l}\text { Potentially } \\
\text { inappropriate drug }\end{array}$ & $\begin{array}{l}\text { n (Population with } \\
\text { the Beers' } \\
\text { criterion) }\end{array}$ & Proportion (\%) \\
\hline $\begin{array}{l}\text { Any angiotensin- } \\
\text { converting enzyme } \\
\text { inhibitor } \\
\text { (ACEi) }\end{array}$ & 34,296 & Amiloride & 1 & 0.0001 \\
\hline \multirow{4}{*}{$\begin{array}{l}\text { Loop diuretic } \\
\text { (furosemide) }\end{array}$} & 33,186 & Lithium & 6 & 0.0001 \\
\hline & & Prazosine & 2155 & 6.4 \\
\hline & & Terazosin & 6 & 0.01 \\
\hline & & Doxazosin & 81 & 0.2 \\
\hline \multirow[t]{2}{*}{ Warfarin } & 2,799 & Naproxen & 1 & 0.03 \\
\hline & & Diclofenac & 1 & 0.03 \\
\hline
\end{tabular}

in 1994 identified a prevalence of $4.52 \%$ in cardiovascular drugs, and lower than those found by Egger et al. in geriatric units $(20.8 \%)$ or Fialová et al. in several European countries (19.8\%). This incidence is also lower than the $26.0 \%$ previously reported in Spain and $48.9 \%$ in Mexico. 4,6,12,14,15

In the Colombian population, Holguín and Orozco, using the Beers' 2002 criteria, found that $21.5 \%$ of the patients received some potentially inappropriate prescriptions, and of these, approximately $34 \%$ corresponded to cardiovascular drugs. ${ }^{16}$ Similarly, another study carried out in Spain by Garcia-Ramos et al. reported a $27.9 \%$ incidence of potentially inappropriate prescriptions in cardiovascular care. ${ }^{17}$

This study found that potentially inappropriate prescriptions were mainly increased in patients older than 80 years of age, especially women, which is in agreement with the results from Aparasu et al. who described how the risk of potentially inappropriate prescriptions increased with age. ${ }^{13}$ In this same sense, Li Mo et al., comparing a population younger than 75 years old with a population older than 80 years old, reported that women (OR: $1.41,95 \% \mathrm{Cl}: 1.10-$ $1.79)$ and age $>80$ years (OR: $1.017,95 \% \mathrm{Cl}: 1.001-1.033)$ were variables independently associated with potentially inappropriate prescriptions. ${ }^{18}$

The most frequently identified potentially inappropriate prescriptions included the use of acetylsalicylic acid in patients over 80 years of age and the prescription of prazosin for the treatment of hypertension in patients over 65 years of age. On the other hand, the work of Garcia-Ramos et al. reported the main drugs involved as amiodarone (25.9\%) followed by doxazosin (22.4\%) and digoxin at doses higher than $0.125 \mathrm{mg}$ in the absence of atrial arrhythmias (20.7\%). ${ }^{17}$ In Mexico, according to the study by Martinez-Arroyo et al., the most frequent in order of use were a regimen of subcutaneous rapid-acting insulin, ranitidine, clonazepam, ketorolac and spironolactone. ${ }^{12}$

Despite the available evidence against the use of acetylsalicylic acid in patients over 80 years of age, which has been established according to the results and recommendations of the USPSTF study, ${ }^{19}$ in this study, it was found that a high proportion of patients $(29.9 \%)$ in this age group had received such a prescription. Older elderly patients are 
those with the highest cardiovascular risk; however, recent studies of prevention using acetylsalicylic acid in other high-risk baseline populations did not find the expected reductions in relative risk. ${ }^{20,21}$ Likewise, it is recognized that the elderly are at higher risk of adverse reactions associated with the use of this drug, reactions that are mainly related to polypharmacy, number of comorbidities, alterations in vision, hearing, mobility and cognition, and increased risk of intra- and extracerebral bleeding. ${ }^{22}$ A study published by Silagy et al. showed that the use of acetylsalicylic acid in individuals over 70 years of age as primary prevention is associated with a significant reduction hemoglobin, whereas the American Diabetes Association does not advise its use for this purpose in patients with diabetes mellitus. ${ }^{23,24}$ In addition, another study, paradoxically, found an increase in the risk of ischemic stroke. ${ }^{25}$

This study has some limitations related to the search parameters being restricted to a single month, which could have excluded those patients who were being prescribed for longer periods of time. In addition, the study design only included patients affiliated with the General System of Social Security in Health, which limits extrapolation of the findings to populations with similar insurance; in addition, the diagnoses were obtained from the records associated with the medical formula and not from the clinical records, so some of these may not have been identified. Likewise, the adverse clinical outcomes for each criterion were not identified. Because of the characteristics of the source of information, it cannot be verified if the elderly were buying medication outside the Colombian health system. In addition, only the Beers' criteria were used to establish the potentially inappropriate character of the prescriptions. There was no control and no recognition of intercurrent events (acute diseases), no clinical records were consulted, no diagnosis was given and no justification was provided by the physician for the use of a particular medication.

\section{Conclusions}

From the findings of this study, it can be concluded that the prevalence of potentially inappropriate prescriptions in an elderly population of patients in Colombia is lower than that reported in different studies; however, the higher frequency of prescriptions of acetylsalicylic acid in patients over 80 years of age should be taken into account given the potential risks that outweigh the benefits. The findings of this study are of paramount importance to the country's pharmacovigilance systems as well as to public health policymakers, as potentially inappropriate prescriptions can translate into adverse events of importance to the patient, the family, and the health system itself. This study also raises the need to re-evaluate the Beers' criteria in our population and, to the extent possible, adjust these criteria according to the reports of pharmacovigilance and active pharmaceutical substances available in the country.

\section{Author contributions}

Alejandro Castro participated in the drafting, data analysis, description of results and discussion. Diego Medina participated in the drafting, data analysis, description of results and discussion. Manuel Machado participated in the drafting, data collection, data analysis, description of results and discussion. Jorge Enrique Machado-Alba participated in the drafting, data analysis, description of results, discussion, critical revision of the article, and evaluation of the final version of the manuscript.

\section{Funding}

This research did not receive any funding source.

\section{Conflict of interest/Disclosure}

The authors declare that they have no conflicts of interest.

\section{Acknowledgements}

To Soffy López by her work in the data base.

\section{References}

1. Rudolph JL, Salow MJ, Angelini MC, McGlinchey RE. The anticholinergic risk scale and anticholinergic adverse effects in older persons. Arch Intern Med. 2008;168:508-13.

2. American Geriatrics Society 2015 Updated Beers Criteria for Potentially Inappropriate Medication Use in Older Adults. J Am Geriatr Soc. 2015;63(11):2227-46.

3. Lam MP, Cheung BM. The use of STOPP/START criteria as a screening tool for assessing the appropriateness of medications in the elderly population. Expert Rev Clin Pharmacol. [Review]. 2012;5:187-97.

4. Willcox SM, Himmelstein DU, Woolhandler S. Inappropriate drug prescribing for the community-dwelling elderly. JAMA. 1994;272:292-6.

5. Lane CJ, Bronskill SE, Sykora K, Dhalla IA, Anderson GM, Mamdani MM, et al. Potentially inappropriate prescribing in Ontario community-dwelling older adults and nursing home residents. J Am Geriatr Soc. 2004;52:861-6.

6. Fialová D, Topinková E, Gambassi G, Finne-Soveri H, Jónsson PV, Carpenter I, et al. AdHOC Project Research Group Potentially inappropriate medication use among elderly home care patients in Europe. JAMA. 2005;293:1348-58.

7. Hovstadius B, Petersson G. Factors leading to excessive polypharmacy. Clin Geriatr Med. 2012;28:159-72.

8. Gallagher P, O'Mahony D. STOPP (Screening Tool of Older Persons' potentially inappropriate Prescriptions): application to acutely ill elderly patients and comparison with Beers' criteria. Age Ageing. 2008;37:673-9.

9. Britten N, Jenkins L, Barber N, Bradley C, Stevenson F. Developing a measure for the appropriateness of prescribing in general practice. Qual Saf Health Care. 2003;12:246-50.

10. American Geriatrics Society updated Beers Criteria for potentially inappropriate medication use in older, adults., J., Am Geriatr, Soc., [Review]. 6042012 616-31.

11. Mallet L, Spinewine A, Huang A. The challenge of managing drug interactions in elderly people. Lancet. 2007;370:185-91.

12. Martínez-Arroyo JL, Gómez-García A, Sauceda-Martínez D. Prevalencia de la polifarmacia y la prescripción de medicamentos inapropiados en el adulto mayor hospitalizado por enfermedades cardiovasculares. Gaceta Médica de México. 2014;150:29-38.

13. Aparasu RR, Mort JR. Inappropriate prescribing for the elderly: beers criteria-based review. Ann Pharmacother. 2000;34:338-46. 
14. Egger SS, Bachmann A, Hubmann N, Schlienger RG, Krahenbuhl S. Prevalence of potentially inappropriate medication use in elderly patients: comparison between general medical and geriatric wards. Drugs Aging. 2006;23:823-37.

15. Miquel MC, Cuervo MS, Silveira ED, Machuca IS, GonzálezBlazquez S, Errasquin BM, et al. Potentially inappropriate drug prescription in older subjects across health care settings. European Geriatric Medicine. 2010;1:9-14.

16. Holguín-Hernández E, Orozco-Díaz JG. Medicación potencialmente inapropiada en ancianos en un hospital de primer nivel Bogotá 2007. Revista de Salud Pública. 2010;12:287-99.

17. Garcia-Ramos S, Garcia-Poza P, Ramos-Diaz F. Evaluación de las prescripciones inapropiadas según los criterios de Beers en los servicios de cardiología y neumología hospitalarios. Rev Calid Asist. 2012;27:169-74.

18. Mo L, Ding D, Pu SY, Liu QH, Li H, Dong BR, et al. Patients aged 80 years or older are encountered more potentially inappropriate medication use. Chin Med J (Engl). 2016;129:22-7.

19. Orces $\mathrm{CH}$. Epidemiology of hip fractures in Ecuador. Rev Panam Salud Publica. 2009;25:438-42.

20. Fowkes FG, Price JF, Stewart MC, Butcher I, Leng GC, Pell AC, et al. Aspirin for Asymptomatic Atherosclerosis Trialists Aspirin for prevention of cardiovascular events in a general population screened for a low ankle brachial index: a randomized controlled trial. JAMA. 2010;303: $841-8$.
21. Ogawa H, Nakayama M, Morimoto T, Uemura S, Kanauchi M, Doi $\mathrm{N}$, et al. Japanese Primary Prevention of Atherosclerosis With Aspirin for Diabetes (JPAD) Trial Investigators Low-dose aspirin for primary prevention of atherosclerotic events in patients with type 2 diabetes: a randomized controlled trial. JAMA. 2008;300:2134-41.

22. Ward SA, Demos L, Workman B, McNeil JJ. Aspirin for primary prevention of cardiovascular events in the elderly: current status and future directions. Drugs Aging. 2012;29:251-8.

23. Pignone M, Alberts MJ, Colwell JA, Cushman M, Inzucchi SE, Mukherjee D, et al. American Diabetes Association; American Heart Association; American College of Cardiology Foundation Aspirin for primary prevention of cardiovascular events in people with diabetes: a position statement of the American Diabetes Association, a scientific statement of the American Heart Association, and an expert consensus document of the American College of Cardiology Foundation. Diabetes Care. 2010;33:1395-402.

24. Silagy CA, McNeil JJ, Donnan GA, Tonkin AM, Worsam B, Campion K. Adverse effects of low-dose aspirin in a healthy elderly population. Clin Pharmacol Ther. 1993;54:84-9.

25. Kronmal RA, Hart RG, Manolio TA, Talbert RL, Beauchamp NJ, Newman A. Aspirin use and incident stroke in the cardiovascular health study CHS Collaborative Research Group. Stroke. 1998;29:887-94. 